\title{
DINAMIKA ISLAM POLITIK PASCA ORDE BARU: Kajian Psikoanalisis Lacanian atas Hubungan KAMMI dan PKS
}

\author{
Ahmad Rizky Mardhatillah Vmar \\ Fakultas Ilmu Sosial dan Ilmu Politik. Universitas Gadjah Mada. \\ Email: ahmad.rizky.m@mail.ugm.ac.id
}

\begin{abstract}
This article aims at analyzing the relations between student movement and political party in post-reform era of Indonesia. KAMMI, a prominent Islamist student movement in Indonesia, often associated with PKS (Prosperous Justice Party) in terms of identity and political practices. It has created 'independence dilemma' for KAMMI because since its first Congress in 1998, this student organization has declared 'independent from all political forces'. This article, using Lacanian psychoanalytical tradition, exposes the forms of KAMMI's subjectivity and PKS interpellation that enable this political party to dominate KAMMI's articulatory practices. The interpellation process is supported with the projection of fantacy, emotion, and mirror in the development of KAMMI since 1998 until present. It leads to PKS creating the KAMMI identity and thus made KAMMI's articulatory practices identical with this party. However, there were several attempts to dislocate the hegemony through several internal reform movements. These attempts, although made contribution to internal dynamics within KAMMI, were unable to create alternative discourse due to several limits of those movements. The case of KAMMI can be a model to explain how other student movements develop and relate to political parties in Indonesian post-reform.
\end{abstract}

Artikel ini bertujuan menganalisis hubungan antara gerakan mahasiswa dan partai politik di Indonesia pasca-reformasi. KAMMI, gerakan mahasiswa Islam terkemuka di Indonesia, kerap dikaitkan dengan PKS (Partai Keadilan Sejahtera) dalam hal identitas dan praktek politik. Hal ini memunculkan 'masalah independensi' KAMMI karena sejak Kongres pertama tahun 1998, 
organisasi mahasiswa ini telah menyatakan 'bebas dari semua tekanan politik'. Artikel ini, dengan menggunakan tradisi psikoanalisis Lacanian, membongkar bentuk-bentuk subjektivitas KAMMI dan interpelasi PKS yang membuat partai politik ini menghegemoni suara KAMMI. Proses interpelasi didukung proyeksi fantasi, emosi, dan cermin pengembangan KAMMI sejak tahun 1998 sampai sekarang. PKS menciptakan identitas KAMMI dan membuat suara KAMMI identik dengan partai ini. Namun, ada beberapa upaya melepaskan hegemoni melalui beberapa gerakan reformasi dari dalam. Upaya reformasi internal, meskipun berkontribusi pada dinamika internal KAMMI, tidak mampu menciptakan wacana alternatif karena kelemahan gerakan tersebut. Kasus KAMMI dapat menjadi model untuk menjelaskan bagaimana gerakangerakan mahasiswa lainnya berkembang dan terkait dengan partai politik di Indonesia pasca-reformasi.

Keywords: student movement, political party, Lacanian psychoanalysis, interpellation, identity

\section{Pendahuluan}

Relasi antara gerakan mahasiswa dan reformasi pasca reformasi telah menjadi diskusi yang cukup hangat dalam literature-literatur politik Indonesia (Aspinall, 2012: 154). Jika analisis di awal reformasi banyak menyebut gerakan mahasiswa sebagai salah satu faktor penentu proses demokratisasi yang selama ini berjalan, maka pasca-reformasi justru aktivisme di kalangan mahasiswa dan gerakan sosial pada umumnya meredup. Proses demokratisasi menjadi alasan utama mengapa gerakan-gerakan tersebut tidak lagi menjadi aktor utama dalam politik Indonesia, karena beberapa eksponen gerakan, baik Islamis maupun kiri, memilih untuk menempuh jalur formal lewat partai politik (Aspinall, 2012: 77). Kendati tidak semua menempuh jalan ini, namun fenomena munculnya partai politik yang notabene dulunya punya embrio dalam aktivisme mahasiswa di tahun 1990 an menjadikan peta politik Indonesia berubah.

KAMMI dan PKS adalah dua entitas yang lahir dari rahim yang sama: 'jamaah tarbiyah' (Muhtadi, 2012: 65). Relasi antara KAMMI dan PKS selalu diwarnai oleh dilema independensi dan dependensi yang tak pernah tuntas hingga 2009 (Kurniawan, 2009: 45). Dalam konteks ini, kita bisa melihat relasi antara KAMMI dan PKS mayoritas aktivis-aktivis KAMMI di awal pembentukannya kini menjadi pengurus PKS (seperti Andi Rahmat, Akbar Zulfakar, dan Fahri Hamzah) dan berkibar lewat jalur parlementer. Implikasinya bukan hanya 'politis' dalam arti KAMMI hanya menjadi 'batu loncatan' untuk berkiprah PKS tetapi juga menjadikan KAMMI berada di 
bawah bayang-bayang politik PKS secara struktural (lihat Machmudi, 2006: 124).

Tulisan ini berniat untuk menyingkap, mengapa hubungan KAMMI dan PKS selama ini bagaikan 'anak' dan 'ayah', seluruh artikulasi KAMMI hampir selalu berada dalam pola permainan yang digariskan oleh sang 'ayah'. Kasus Muktamar Luar Biasa di tahun 2009, misalnya, mencerminkan praktik pendisiplinan ketika KAMMI melakukan sesuatu yang melanggar perintah PKS dengan bermanuver mendukung salah satu calon presiden yang tidak direstui oleh PKS. Praktik serupa terjadi baik dari tingkat komisariat hingga pusat. Relasi tersebut juga muncul ketika gerak-gerik KAMMI di tahun-tahun politik menghadapi dilema dependensi dan independensi (Syarifuddin, 2004). Oleh sebab itu, relasi antara KAMMI dan PKS tersebut perlu dikupas secara lebih teoretik dan mendalam.

Relasi antara KAMMI dan PKS yang menyerupai 'anak dan ayah' ini akan sangat relevan jika kita dipandang dalam perspektif psikoanalisis yang diajukan oleh Jacques Lacan. Yang menarik dari pendekatan Lacan adalah bahwa setiap perilaku individual tidak dipahami dari 'apa yang ia lakukan' secara sadar, melainkan pada konstruksi ketidaksadaran yang menyebabkan ia melakukan hal tersebut. Bagi Lacan, ketidaksadaran berstruktur seperti Bahasa dan mempunyai signifikansi dalam menentukan praktik kesadaran manusia/subjek (Thom, 2003: 36). Format ketidaksadaran inilah, alih-alih kepentingan mahasiswa, yang memproliferasi praktik diskursif KAMMI selama ini. PKS muncul sebagai manifestasi 'Jamaah Tarbiyah' yang merupakan induk dari aktivitas dakwah mahasiswa dan, pada perkembangannya, membuat KAMMI harus menghadapi dilema-dilema tertentu terkait dengan tindakantindakan politiknya.

Artikel ini berargumen bahwa relasi antara KAMMI dan PKS sangat ditentukan oleh formasi ketidaksadaran yang menentukan subjektivitas KAMMI. Selama ini, PKS bertindak sebagai 'aturan sang ayah' yang menentukan subjektivitas KAMMI dan menyebabkah hegemoni partai politik tumbuh di atas gerakan mahasiswa. Proses tersebut, mengikuti psikoanalisis Lacanian, beroperasi di ruang ketidaksadaran KAMMI. Untuk melihat relasi KAMMI dan PKS dalam ruang ketidaksadaran, psikoanalisis Lacanian akan memberikan kita sebuah penjelasan yang lebih adequate mengenai bagaimana selama ini KAMMI berelasi dengan PKS. 


\section{Kerangka Teoretik: Memahami Psikoanalisis Lacanian}

Pemikiran Psikoanalisis Lacan tak bisa dilepaskan dari pemikir psikologi terkemuka, Sigmund Freud. Freud pertama kali menyatakan bahwa 'diri' manusia adalah diri yang terbelah (split) antara kesadaran dan ketidaksadaran. Dalam terminology Freudian, yang kemudian diteruskan Lacan, praktik kesadaran manusia ditentukan oleh ketidaksadaran. Ia menolak slogan Cartesian yang selama ini menjadi 'ideologi' bagi positivisme Barat: Cogito Ergo Sum 'Aku' berpikir, maka 'aku' ada. 'Aku' yang dipahami dalam logika Cartesian adalah aku yang absolut, kuat, dan mandiri.

Gagasan ini menempatkan 'aku' manusia sebagai centre dari segala bentuk aktivitas. Terminologi Freudian mencoba untuk mendestabilisasi pemahaman Cartesian ini dengan mempertanyakan 'Aku' (Cogito). Benarkah bahwa eksistensi 'Aku' itu ditentukan oleh kesadaran (Cogito)? Menurut Freud, ketidaksadaran itu muncul sebelum kesadaran. Namun, ketidaksadaran itu adalah sesuatu yang merepresi kesadaran dalam bentuk neurosis atau obsesi. Ia melihat, misalnya, dalam kasus 'manusia tikus' (ratman) manusia yang memiliki obsesi-obsesi neurotic tertentu sebagaimana dianalisis dalam kasus psikiatri yang ditangani Freud yang menurutnya mencerminkan bagaimana ketidaksadaran merepresi kesadaran manusia. Untuk menghindari represi dan neurosis itu, Freud kemudian mendeklarasikan sebuah istilah: Wo Es War, Soll Ich Werden Di mana ada Id, di situ ada Ego. Agar ketidaksadaran tidak merepresi subjek, Freud berargumen untuk 'memperkuat Ego, agar ia tidak bisa direpresi oleh ketidaksadarannya.

Lacan tidak setuju hal tersebut. Baginya, penemuan bahwa 'ketidaksadaran' itu direpresi bukan berarti bahwa 'ketidaksadaran' itu harus dikendalikan baginya ini tidak mungkin. Pertanyaan yang diulas Lacan bukanlah 'bagaimana mengendalikan ketidaksadaran', tetapi justru lebih mendasar: bagaimana ketidaksadaran itu menciptakan proyeksi mengenai 'diri' mahasiswa. Bagi Lacan, 'kesadaran' manusia, yang diejawantahkan dalam konsepsi mengenai 'diri' identitas pada dasarnya adalah sesuatu yang ilusif. Ia diproyeksikan oleh sistem penandaan yang tak pernah berada pada posisi 'tetap'. Pada titik inilah, Lacan memulai analisisnya tentang 'ketidaksadaran' itu dalam bentuk perkembangan manusia.

Konsep perkembangan manusia dikembangkan oleh Lacan dari konsep 'Oedipus Complex' yang pada awalnya diajukan oleh Freud. Lacan melihat perkembangan manusia dari tiga fase: 'yang nyata' (The Real), Imajiner, dan Simbolik. Tiga fase ini dilihat dari perkembangan manusia ketika ia menjadi 
bayi hingga ia dewasa. Ketika seseorang menjadi bayi, ia hidup pada fase The Real. Pada masa ini, manusia tidak bisa dipisahkan dari ibunya. Ia melihat kehidupan pada apa yang ada di sekitarnya. Tak ada perbedaan antara bayi dengan 'yang-Lain', karena bayi menggantungkan hidup pada ibu yang menyapih dan membesarkannya. Dengan demikian, ia hanya mengenal 'hasrat' yang dipenuhi oleh objek ibunya. Ketika ia perlu makanan, ia mendapatkan dari ASI. Ketika ia butuh kenyamanan, ia mendapatkannya dari ibunya. Dan lain sebagainya. Pada titik ini, bayi mengenal "kebutuhan", tetapi kebutuhan itu langsung terpuaskan dan terpenuhi oleh ibunya.

Ketika sang bayi telah berumur sekitar 6-18 bulan, menurut Lacan, ia mulai mengenal lingkungan di luar dirinya. Pada titik itulah ia mulai mengenal ada 'sesuatu' di luar dirinya The Other ('yang lain'). Ia mengenal 'Yang-Lain' karena Ia sudah memiliki kesadaran bahwa ia terpisah dari lainnya. Kesadaran akan 'keterpisahan' tersebut kemudian mendatangkan gagasan tentang 'kehilangan', ia sadar bahwa ia berpisah dari ibunya. Pada titik inilah muncul konsep penting: Lack perasaan bahwa individu adalah makhluk yang serba-berkekurangan.

Gagasan tentang 'kehilangan' ini, dalam konteks anak, tak bisa dilepaskan dari munculnya seorang figure baru: 'Ayah' (Father). Ayah menjadi The Other yang memisahkan anak dari ibunya. Seorang anak yang merasa 'kehilangan' pada mulanya akan mencari 'yang hilang' itu pada ibunya. Namun, kehadiran 'sang ayah' membuatnya tidak mungkin mencari hal itu pada ibunya. Sang ayah memiliki kekuatan untuk mengkastrasi/memisahkan si anak dari ibunya, karena: (1) sang-ayah memiliki kepentingan untuk memiliki ibunya, (2) sang ayah mempunyai kepentingan untuk mengenalkan si anak tentang 'kebudayaan' (Polimpung, 2008: 114). Kemarahan 'sang ayah' terhadap anaknya inilah yang disebut sebagai 'in the name of Father' atas nama ayah', yang mengatur seluruh artikulasi yang dilakukan oleh si anak.

Karena si bayi sadar bahwa ia terpisah dengan The Other, dan bahwa ia memiliki kekurangan akibat keterpisahannya tersebut, ia kemudian mulai mencari tahu: siapakah 'aku'? Di sinilah Lacan menyebut sebagai dimulainya fase Cermin. Seiring keluarnya bayi dari fase The Real, ia mulai masuk pada fase cermin yang memulai proses identifikasi diri. 'Aku' mengidentifikasi dirinya, menurut Lacan, dengan bercermin pada The Other. Cermin itu tidak memberikan gambaran yang utuh dan objektif pada identifikasi diri 'Aku'. Inilah yang disebut Lacan sebagai 'mispersepsi' ketika The Other yang menjadi 'Cermin' menarik subjek untuk bercermin pada dirinya (Hey, subjek, 
berkacalah padaku!) si subjek langsung mengidentifikasi dirinya pada cermin tersebut ('hey, itu aku!'). Namun, apa yang ia lihat di cermin sejatinya bukanlah dirinya sendiri, itu adalah citraan yang diberikan oleh 'cermin' (Polimpung, 2008: 115).

Lacan menyebut fase 'Cermin' ini sebagai fase imajiner, fase pembentukan 'diri' ketika seorang anak memproyeksikan diri mereka dari citra yang dilahirkan oleh cermin. Argumennya, fase Cermin adalah fase yang formatif terhadap keberadaan 'aku'. Identitas yang muncul dalam fase Cermin ketika subjek memproyeksikan citraannya sebagai 'aku' menentukan bagaimana 'aku' nantinya terbentuk. Cermin, dalam bahasa Lacan, memberikan meconnaissance mispersepsi, kesalahan pengakuan, dsb. Citraan yang dimispersepsi itu kemudian ditetapkan maknanya oleh 'the name of father' (Lacan, 1977: 3).

Namun, proses identifikasi diri melalui cermin itu hanya akan berjalan jika subjek 'aku' menyatakan dirinya dalam bahasa. Artinya, citraan yang ditangkap oleh individu dari cermin itu baru menjadi 'identitas' jika si subjek menyatakan identitasnya dalam bahasa. Inilah yang disebut oleh Lacan sebagai fase 'simbolik'. Ketika ia mulai berbicara, The Other yang selama ini ditangkap melalui cermin kemudian mulai distrukturkan dalam sebuah sistem penandaan yang fixed. Pada titik itulah identitas diri mulai ditetapkan.

Menurut Lacan, proses penetapan identitas yang berlangsung melalui bahasa itu pada dasarnya hanya dimungkinkan jika ada Phallus sesuatu yang menjadi 'centre' dari sistem penandaan yang dibuat. Sebuah tatanan simbolik hanya mungkin ada jika ada sesuatu yang berada di pusat tatanan tersebut dan mengendalikan sistem penandaan yang beroperasi melalui bahasa tersebut. Ketika si anak menyatakan diri sebagai 'aku' dalam bahasa yang ia gunakan, 'Aku' yang ia maksudkan sejatinya diidentifikasikan oleh sebuah diskursus tertentu yang mengikat dan membuat makna 'aku' tersebut menjadi bersifat tetap. Lacan tidak percaya 'aku' adalah sesuatu yang kuat dan tetap.

Bagi Lacan, identitas 'Aku' sejatinya adalah identitas yang selalu tergelincir dalam sistem penandaan yang berjalan siklikal dan terus-menerus. Seorang 'anak' menyatakan diri sebagai 'aku' karena ia bukanlah The Other ini yang cihasilkan dari identifikasi di fase cermin. Pertanyaannya, kenapa kemudian identitas 'aku' ini bisa ditetapkan oleh sebuah sistem pemaknaan tertentu? Konsep tentang Lack kekurangan yang diderita seorang anak dari fase cerminnya menjadi kata kuncinya. Ketika seorang anak mengetahui bahwa ia terpisah dari ibunya, ia kemudian menyadari bahwa hasrat yang ia miliki tidak akan lagi dapat terpuaskan. Maka dari itu, ia mencari sumber 'hasrat' yang 
lain. Cermin The Other memberikan sumber 'hasrat' tersebut dan mengikat hasrat tersebut dalam sebuah sistem pemaknaan tertentu yang bersifat stabil. Sistem pemaknaan tersebut, menurut Lacan, terstruktur dalam bahasa yang disampaikan oleh si anak.

Lacan melihat bahasa dalam kategori yang sama dengan yang digunakan oleh Ferdinand de Saussure. Bagi Lacan, bahasa itu membentuk sebuah 'rantai penandaan' (chain of signification) tertentu. Rantai penandaan tersebut mengimplikasikan sebuah sistem makna yang tak pernah stabil. Sebuah 'penanda' merupakan 'petanda' bagi kata yang lain. Bahasa, dengan demikian, dibangun di atas konsep tentang 'kekurangan' (lack) karena tidak ada satupun yang bisa memenuhi hasrat berbahasa secara utuh (Lacan, 1977: 27). Begitu juga dengan 'hasrat'. Hasrat adalah sesuatu yang tak pernah utuh, serba berkekurangan, sehingga 'hasrat' juga dibangun di atas sebuah sistem penandaan yang tak pernah stabil. Identifikasi diri menjadi stabil karena ia diikat oleh semacam Phallus tertentu.

Apa yang disebut oleh Lacan sebagai 'In the name of Father' menjadi sebuah hal penting dalam identifikasi diri. Identifikasi terhadap 'aku' sejatinya adalah identifikasi The Other yang terus-menerus menggelincir dan tidak pernah utuh. Namun, ia ditetapkan oleh satu penanda yang superior inilah the name of father. The Other yang superior ini bukanlah sesuatu yang fixed, melainkan bersifat hegemonik kemampuannya untuk mengatur orang lain berhubungan dengan kemampuannya untuk mengendalikan persetujuan/penolakan orang lain (Laclau dkk, 1986: 119).

In-the-name of father menjadi instrument untuk mengenalkan anak pada 'budaya', Sang Ayah mengendalikan si anak dengan aturan-aturan (kemarahan) yang ia miliki untuk mendisiplinkan si anak. Meminjam Foucault, diskursus tentang 'Sang Ayah' beroperasi dengan logika disiplin dan hukuman, ia mengatur, mendisiplinkan, dan mengendalikan anak agar mau menerima budaya yang ia tanamkan. Sehingga, walaupun sang-ayah sudah meninggal, subjek masih patuh pada apa yang ia tanamkan. Pada titik inilah hasrat diatur untuk masuk dalam sistem penandaan tertentu yang stabil.

Dengan masuknya manusia kepada tatanan simbolik bahasa, budaya, dan sejenisnya maka si anak masuk pada fase 'kedewasaan'. Fase ini ditandai oleh masuknya si anak pada diskursus tentang gender. Menurut Lacan, si anak hanya bisa melihat apa yang bukan pada dirinya. Ia mengambil contoh pada identifikasi oleh dua orang kakak-beradik, laki-laki dan perempuan, ketika ia duduk di sebuah gerbong kereta api. Menurut anak laki-laki, ia 
berada pada bagian perempuan dan menurut anak perempuan ia berada pada wilayah laki-laki (Lacan, 1977: 115). Seperti itulah bahasa. Identifikasi yang masuk pada fase simbolik bahasa dilakukan dengan menunjuk pada yang lain, bahwa 'aku' adalah bukan 'yang lain', atau dalam konteks oposisi biner seperti laki-laki dan Perempuan, 'Aku' laki-laki bukanlah 'Aku' Perempuan. Konstruksi budaya memainkan peran semacam ini.

\section{Kelahiran, Identifikasi, dan Subjektivisasi KAMMI}

Dengan melihat analisis Lacan di atas, kita bisa berargumen bahwa relasi 'ayah dan anak', yang dalam bahasa Ilmu Politik digambarkan sebagai 'relasi patron-klien' menggambarkan bahwa ada semacam konstruksi budaya (Phallus) yang mendisiplinkan klien dan menjadikannya berada pada sebuah sistem penandaan tertentu. Begitu juga ketika kita membaca relasi KAMMI dan PKS. Tak diragukan lagi, walaupun elit-elit KAMMI menyatakan bahwa KAMMI bersifat independen dan tak berhubungan dengan PKS, terlihat peran sentral alumni yang berada di PKS dalam mengendalikan aksi-aksi gerakan KAMMI dan menjadikan PKS sebagai 'karier politik masa depan' bagi aktivis-aktivis KAMMI. Konsekuensinya, walaupun ada narasi tentang 'independensi', relasi-relasi yang dibangun juga menjadi sangat klientelistik, dalam arti aktivis-aktivis Tarbiyah, alumni KAMMI yang berkecimpung di PKS sangat besar perannya dalam menentukan arah gerak KAMMI (Muhtadi 2012: 67).

Pertanyaan yang perlu kita ajukan adalah, mengapa dengan relasi klientelistik tersebut, mengapa proses kultural tersebut bertahan hingga kini? Dan mengapa relasi kultural ini mengakar sedemikian rupa, hingga jarang sekali ada kader KAMMI yang berani mempertanyakannya, dan dengan demikian menutup kemungkinan perubahan? Pada titik ini, kritik kebudayaan yang ditawarkan melalui psikoanalisis Lacanian menjadi cukup relevan untuk membongkar praktik-praktik diskursif tersebut.

Saya akan memulai dari proses perkembangan KAMMI ketika ia lahir fase Pra Oedipal dalam terminology Lacanian. Andi Rahmat dan Muhammad Najib menggambarkan proses kelahiran ini secara cerdas dalam bukunya, "Gerakan Perlawanan dari Masjid Kampus"., KAMMI dilahirkan dari dua variable penting: 'masjid' dan 'kampus' (Rahmat dkk, 2007: 10). KAMMI tidak lahir dari 'deklarasi' 29 Maret 1998. KAMMI, lahir ketika aktivis-aktivis Muslim membawa embrio yang bernama Jemaah Tarbiyah dari Mesir. Oleh sebab itu, memahami KAMMI harus ditarik jauh ke belakang, di tahun 1980 
an, ketika aktivis dakwah memasuki Indonesia dan beroperasi di masjid-masjid kampus (Imam, 2010: 9).

KAMMI lahir dari aktivis-aktivis masjid yang kemudian bertransformasi menjadi kekuatan politik setelah krisis ekonomi bergulir di tahun 1998. Aktivis-aktivis masjid kampus ini adalah mereka yang membawa kesalihan dan mengartikulasikannya dalam pergerakan mahasiswa. Dimulai dari adaptasi gagasan-gagasan Ikhwanul Muslimin yang dibawa melalui proses penerjemahan buku pada tahun 1980an, aktivis-aktivis dakwah yang bernaung dalam LDK mulai mengartikulasikan 'Islam' dalam kerangka 'dakwah kampus', menarik aktivis-aktivis mahasiswa dan mulai mendakwahkan Islam di kalangan mereka. Tidak ada aksi politik di sini, yang ada hanyalah dakwah kepada mahasiswa yang diatur melalui tanzhim/organisasi yang bersifat 'amniyah/rahasia (Machmudi, 2006: 179).

'Diskursus' yang ditampilkan oleh Jemaah Tarbiyah di era awal pembentukan dan konsolidasinya di Indonesia adalah diskursus tentang 'negara Islam' (Machmudi, 2006: 185). Bagi aktivis Jemaah Tarbiyah, pembentukan basis-basis sosial untuk menuju negara Islam menjadi penting. Maka dari itu, Jemaah Tarbiyah menggunakan halaqah (kelompok-kelompok kecil) sebagai bagian penting dari pembangunan basis sosial dakwah. Pembangunan basis dakwah tersebut, pada mulanya dilakukan di kampus-kampus. Mengapa kampus? Jawaban sederhananya: kampus menjadi 'sarana' artikulasi setelah pemerintah Orde Baru mendepolitisasi aktivitas Islam Politik (Sudarsono, 2010: 12).

Jika menggunakan term Lacanian, aktivitas 'dakwah kampus' ini adalah fase pra-oedipal. Mahasiswa masih bersatu dengan Liyan (The Other), yaitu Jemaah Tarbiyah yang berbasis di masjid-masjid kampus (Machmudi, 2006: 165). Ia hanya mengenali lingkungan dari gerakan dakwah itu. Kebutuhan mereka, yaitu dakwah dan artikulasi keagamaan, terpenuhi dengan dakwah kampus itu. Dengan berdakwah dan menampilkan kesalihan di kampus, 'hasrat' untuk meng-Islamisasi lingkungan terpenuhi. Mahasiswa berada pada fase The Real, kondisi 'state of nature' ketika aktivitas dakwah hanyalah pada seruan keagamaan di kampus atau kajian-kajian keagamaan di masjid. Mahasiswa dan gerakan dakwah adalah satu, tidak terpisahkan. Inilah fase ketika KAMMI masuk pada proses 'ideologisasi' dan mencari jati diri identitasnya setelah lahir.

Namun, kondisi 'pra-oedipal' ini tak bisa terus-menerus terjadi seperti itu. Pada tahun 1998, 'negara' mengalami krisis. Gerakan dakwah mengharuskan 
dirinya tampil ke panggung politik. Melalui apa? Tentu saja, mahasiswa! Inilah saat ketika mahasiswa keluar dari fase The Real dan harus mengenal lingkungannya. Pada tanggal 29 Maret 1998, ketika pertemuan FSLDK X baru saja ditutup di Universitas Muhammadiyah Malang, aktivis-aktivis dakwah ini kemudian sepakat membentuk KAMMI.

Lahirnya KAMMI tidak bisa hanya dipandang dari inisiatif anak-anak muda. Pertanyaannya, sebagaimana ditanyakan beberapa penulis, bagaimana mungkin organisasi yang baru lahir tak sampai sebulan bisa menggerakkan massa hingga ribuan mahasiswa? (Sudarsono, 2010: 17) Dalam catatan yang tersebar di milis KAMMI, kelahiran KAMMI juga merupakan ikhtiar aktivisaktivis Jemaah Tarbiyah yang bukan lagi berada pada posisi mahasiswa. Ketua KAMMI pertama, Fahri Hamzah, dan Sekretaris Jenderalnya, Haryo Setyoko, bukanlah peserta formal FSLDK X (Meskipun Fahri dan Haryo adalah tokoh LDK ketika zamannya). Campur tangan tokoh-tokoh senior Jamaah Tarbiyah masih sangat besar.

Apa artinya ini? Dalam perspektif Lacanian, aktivis dakwah kampus pada saat itu 'diharuskan' untuk keluar dari fase The Realnya. Medan yang ditempuh adalah pertemuan FSLDK. Mereka keluar dari fase Yang Real untuk kemudian berhadapan dengan dunia sekitarnya. Pada saat itulah, mereka mengenal Liyannya. Saat itulah mereka kemudian sadar bahwa 'diri' mereka adalah diri yang Lack, serba berkekurangan. Pencarian atas 'hasrat' yang tak dapat dipuaskan dari kampus itu kemudian dicari dalam politik jalanan.

Di sini, peran 'Father' (Sang Ayah) sangat sentral. Dalam perspektif Lacanian, tokoh-tokoh senior Jemaah Tarbiyah yang kemudian mendeklarasikan berdirinya PKS itu adalah 'Sang Ayah'. Kemampuan mereka untuk 'memaksa' si anak (mahasiswa) turun ke ranah politik dan dimobilisasi adalah kemampuan mereka untuk meng-kastrasi/memisahkan si anak dari ibunya. Sang Ayah punya kepentingan untuk mengenalkan anak-anak mahasiswa itu dengan 'kebudayaan', yaitu politik praktis di era transisi rezim Suharto, dan dengan demikian menginjeksi mereka dengan logika berpikir yang diinginkan sang Ayah.

Peran 'Sang Ayah' itulah yang kemudian menjelma pada 'diri' PKS. Di sini, kita tidak mendefinisikan 'Sang Ayah' itu lahir dalam PKS. PKS, dalam perspektif ini, hanyalah penjelmaan 'Sang Ayah' dalam bentuk Yang-Lain setelah ia berhasil mengkastrasi mahasiswa. 'Sang Ayah' itu sudah lahir jauh sebelumnya, ketika aktivis-aktivis Jemaah Tarbiyah melakukan konsolidasi bawah tanah. Mahasiswa dakwah kampus, atau KAMMI, adalah 'anak' yang 
harus dibesarkan dalam satu kebudayaan tertentu, yaitu demokratisasi.

Di sinilah 'si anak' atau KAMMI menghadapi proses 'cermin' sebagaimana diperkenalkan Lacan. Ketika si anak keluar dari fase The Real, ia menyadari bahwa ia harus mendapatkan kenyamanan narsistik 'untuk menjadi' seseorang. Argumen Lacan, proses tersebut diperoleh melalui pencerminan. Begitu juga KAMMI. Ketika KAMMI keluar dari fase The Real dan masuk pada dunia politiknya begitu reformasi 1998, KAMMI harus mengidentifikasikan dirinya. Ia kemudian bercermin pada The Other yang ada di sekitarnya.

Namun, sebagaimana kata Lacan, cermin itu tidak memberikan sesuatu yang utuh, melainkan mispersepsi. Ketika KAMMI bercermin ke luar, ia bercermin pada realitas perubahan sosial yang diejawantahkan melalui aksi-aksi demonstrasi. Dari sinilah, gagasan mengenai 'agent of social change' kemudian diinjeksikan. 'Agent of Social Change' yang dimaksud, tentu saja, bercermin pada realitas bahwa gerakan mahasiswa adalah gerakan-gerakan yang berbasis pada aksi demonstrasi. 'Cermin' ini diperkuat oleh pembenaran dari Father yang menyatakan bahwa 'ya, kamu memang agent of social change yang harus melakukan demonstrasi', sehingga cermin ini menjadi basis identifikasi KAMMI.

Kita bisa lihat contoh, misalnya, kondisi ketika KAMMI dideklarasikan. Ketika itu, gerakan mahasiswa baru saja menghadapi krisis ekonomi yang membuat ketidakpercayaan publik terhadap presiden Suharto meluas. Terma "Kesatuan Aksi" menjadi basis identifikasi awal KAMMI. Ketika ia awal mula didirikan, ia sadar bahwa 'hasrat narsistik' mereka tidak bisa terpuaskan hanya dengan mencarinya kepada ibunya masjid kampus. Keberadaan 'sang Ayah' (tanzhim tarbiyah) yang ingin anaknya terlibat dalam politik juga membuat sang Anak takut dan tunduk pada perintah 'Sang Ayah' Ia kemudian keluar dari fase The Real mereka di kampus, dan mencari pemuasan hasratnya di luar. Ia mencari 'cermin' dan melihat kepada sekelilingnya, krisis ekonomi. Ia segera bercermin dan mengatakan, "hey, aku adalah agent of social change, aku harus demonstrasi!" Dan hal ini diafirmasi oleh The Other, "kalian adalah gerakan aksi/protes terhadap Suharto”. Identifikasi inilah yang kemudian mengantarkan KAMMI pada praktik berbahasa aksi-aksi gerakan.

Namun, proses pencerminan tersebut baru sebatas konstruksi. Identitas itu ditetapkan melalui fase berikutnya, yaitu fase simbolik. Di fase ini, KAMMI sudah mengenal 'bahasa', yang diejawantahkan dalam aksi-aksi gerakan. KAMMI mulai mengenal 'bahasa' ketika ia dideklarasikan pada tahun 1998 oleh aktivis-aktivis FSLDK X. KAMMI mula-mula membahasakan diri mereka 
dengan 'Deklarasi Malang'. Deklarasi ini menyatakan,

"Didasari keprihatinan mendalam terhadap krisis nasional yang melanda negeri ini dan didorong tanggung jawab moral terhadap penderitaan rakyat yang masih terus berlangsung, serta itikad baik untuk berperan aktif dalam proses perubahan dan perbaikan, maka kami segenap mahasiswa muslim Indonesia mendeklarasikan lahirnya: Kesatuan Aksi Mahasiswa Muslim Indonesia" (Deklarasi Pendirian KAMMI, 1998)

Ada dua hal yang bisa diambil dari deklarasi di atas. Pertama, dasar pembentukan. KAMMI dibentuk atas dasar: (1) keprihatinan mendalam terhadap krisis nasional, (2) tanggung jawab moral terhadap penderitaan rakyat, dan (3) itikad baik untuk berperan dalam proses perubahan. Dasar ini harus kita lihat sebagai 'hasil pencerminan' KAMMI pada waktu itu. The Other memberikan cermin kepada KAMMI bahwa "kondisi saat ini memang krisis, mahasiswa diperlukan untuk berperan”. KAMMI kemudian memersepsikan diri sesuai dengan krisis tersebut. Inilah yang menjadi dasar identifikasi 'diri' KAMMI. Kedua, bentuk gerakan. Setelah bercermin, apa yang KAMMI lakukan? Tentu saja, membahasakan diri sesuai apa yang diberikan oleh cermin! Ia kemudian menutupi kekurangan-kekurangan yang ada sesuai dengan citraan yang diberikan oleh cermin.

Sebagai contoh, seorang anak ingin mencari tahu apakah dia 'ganteng' atau tidak. Ia kemudian bercermin, "apakah saya lebih ganteng dari orang lain dengan pakaian ini"? Cermin bisa saja memberikan jawabannya, "pakaianmu kurang match dsb". Apa yang diberikan oleh cermin itu, tentu saja, telah terlebih dulu dibandingkan oleh si anak dengan penampilan orang lain (The Other). Si anak kemudian akan mengubah penampilannya dan mencari pakaian yang pas, yang membuat dirinya terlihat lebih ganteng. Begitu juga dengan KAMMI. Ia membandingkan dirinya dengan The Other dan kemudian membuat format gerakan yang berbasis aksi massa dengan pencerminan tersebut.

Gerakan reformasi 1998 terkenal dengan euforia demonstrasi besarbesaran. Alat penekan Suharto pada waktu itu, yang paling efektif, adalah demonstrasi. Sehingga, pada waktu itu KAMMI masih populer dengan aksi-aksi demonstrasi yang membuatnya sangat dikenal sebagai demonstran-demonstran ulung. KAMMI bergerak dengan melakukan aksi 10.000 massa di Mesjid al Azhar, Jakarta, kemudian bergerak dalam aksi-aksi massa besar di kota-kota besar lain (Sidiq, 2003: 76). Puncaknya, pada 20 Mei 1998, KAMMI yang difasilitasi Ketua Umum PP Muhammadiyah Amien Rais berencana menggelar 
aksi besar di Monas, yang akhirnya tidak jadi dilaksanakan karena ancaman kepolisian (Sidiq, 2003: 77). Aksi kemudian dipindahkan ke Gedung DPR/ MPR dan akhirnya, bersama-sama elemen mahasiswa lain, menyerukan penurunan Suharto.

Format gerakan aksi inilah yang menandai KAMMI masuk pada fase simbolik fase bahasa. Di sini KAMMI sudah mengenal tuntutan yang dibahasakan dalam bentuk aksi-aksi demonstrasi. KAMMI ingin memuaskan 'hasrat narsistik'nya, menciptakan masyarakat dan negara yang Islami, melalui demonstrasi-demonstrasi penolakan terhadap Suharto. Karena bercermin dengan krisis ekonomi dan krisis politik pada waktu itu, KAMMI mengidentifikasikan dirinya sebagai sebuah 'gerakan aksi'. Sehingga, pada titik ini, kita bisa melihat bahwa ketika KAMMI masuk pada fase simbolik, ia mulai mengenal 'cara' memuaskan hasratnya dan mulai mengenal 'kebudayaan' berupa politik praktis.

\section{Munculnya PKS: Superioritas 'Sang Ayah'}

Namun, pada 21 Mei 1998, Suharto akhirnya benar-benar jatuh! Ini menjadikan Kini, yang jadi persoalan bukanlah 'bagaimana menjatuhkan Suharto' tetapi bagaimana mengelola Indonesia yang baru saja ditinggalkan penguasanya. Semua kekuatan politik kemudian berlomba-lomba untuk membuat partai politik dan tampil ke pentas demokratisasi sebagai cara untuk men-define Indonesia. Tak ketinggalan pula, Jemaah Tarbiyah. Tak lama sesudah reformasi, ia mentransformasikan dirinya menjadi sebuah partai politik: Partai Keadilan nanti berubah jadi Partai Keadilan Sejahtera (PKS).

Pertanyaannya, apa kaitan hal ini dengan posisi subjek KAMMI? Ketika KAMMI keluar dari fase The Real, ia menghadapi rasa 'kehilangan' yang kemudian menumbuhkan perasaan lack serba berkekurangan pada diri subjek. Rasa kehilangan tersebut kemudian menimbulkan semacam 'lubang yang menganga' pada diri subjek yang membuatnya harus menutupi lubang tersebut (Polimpung, 2008: 116). 'Lubang yang menganga' itulah yang dinamakan dengan hasrat. Berbeda dengan 'kebutuhan' di fase real, yang bisa dipuaskan oleh ibu biologisnya, hasrat tak bisa dipuaskan. Itulah yang membuat KAMMI kemudian mengidentifikasi dirinya.

Pada akhir tahun 1998, KAMMI menggelar Muktamarnya yang pertama dan memutuskan untuk menjadi Organisasi Masyarakat (Ormas). Sebelumnya, Jemaah Tarbiyah sudah terlebih dulu bertransformasi menjadi partai politik. Konsekuensinya, hubungan antara 'si anak' dan 'sang Ayah' menjadi cukup 
dilematis. Sebab, dengan keberadaan 'sang Ayah' seperti itu, anak harus menjadikan relasinya dengan 'Sang Ayah' sebagai relasi yang 'politis' dan akan bertabrakan dengan identitasnya sebagai 'Gerakan Mahasiswa' sesuatu yang telah dikonstruksi sejak keluarnya KAMMI dari fase The Real. Kondisi ini akan berbeda jika Tarbiyah memilih untuk menempuh jalur Ormas, misalnya, yang berarti tidak membuat setiap artikulasinya sebagai pengorganisasian politik.

Di Garis Besar Haluan Organisasi yang disahkan di Muktamar tersebut, tertera penjelasan bahwa, "KAMMI sebagai bagian dari elemen gerakan mahasiswa yang mengedepankan gerakan moral dan intelektual tetap bersikap independent, kritis, moralis dan reformis. Posisi-posisi itu harus selalu menjadi sikap KAMMI dalam memandang persoalan-persoalan bangsa yang terkait dengan partai politik. KAMMI sebagai organisasi mahasiswa bercorak kepemudaan dan kemahasiswaan harus tetap menjaga kemurnian serta konsistensinya agar tidak terseret secara langsung dalam gerakan politik praktis" (GBHO KAMMI, Pasal 10)

Dalam berhubungan dengan partai politik, KAMMI membahasakan dirinya dengan terminologi 'gerakan moral' dan 'gerakan intelektual'. 'Bahasa' gerakan moral dan gerakan intelektual tersebut dikontraskan dengan gerakan politik praktis yang diasosiasikan dengan partai politik. Untuk menjembatani relasi mereka dengan gerakan politik praktis tersebut, digunakan kata-kata 'independen, kritis, reformis, dan moralis'. Apa maksudnya? Jika dilihat dari teks ini, KAMMI ingin menegaskan identitasnya sebagai gerakan mahasiswa, yang pada waktu itu adalah gerakan yang independen dan bergerak pada basis kemahasiswaan.

Hal ini merupakan satu catatan penting. Jika mengikuti argument Lacanian, 'identitas' itu pada dasarnya adalah sesuatu yang bersifat selalu tergelincir, tidak pernah tetap. Namun, ketergelinciran yang terus-menerus itu kemudian berhenti jika ada satu penanda utama yang menetapkan maknanya. Begitu juga dengan identitas 'mahasiswa'. Tidak ada yang bisa menyatakan bahwa 'mahasiswa' itu siapa. Bagi aktivis, ia adalah 'bukan partai politik', 'bukan pemerintah', 'bukan rezim otoriter', dan seterusnya. Ia adalah apa yang diberikan oleh The Other, yang memiliki kemampuan untuk mengartikulasi hasratnya dan memberikan makna yang tetap.

Namun, ada satu penanda yang menjangkarkan maknanya sehingga 'bahasa' menjadi sebuah pemaknaan yang tetap. Inilah yang kemudian disebut sebagai The Master Signifier. Jika kita lihat dalam teks Garis Besar Haluan Organisasi tersebut, identitas KAMMI ditetapkan oleh satu penanda utama: 
'mahasiswa-dakwah'. Penanda utama itulah yang kemudian mengakhiri ketergelinciran makna yang menyertai proses identifikasi KAMMI. Dengan menandai artikulasinya sebagai 'mahasiswa', Diri KAMMI secara jelas ditandai: ia adalah gerakan moral dan gerakan intelektual yang merupakan negasi dari gerakan politik praktis.

Pada titik inilah, KAMMI mengenal 'bahasa'. Si anak (KAMMI), yang sudah mencapai fase simbolik, kemudian harus masuk pada format kebudayaan tertentu. Ketika ia mengenal bahasa, ia harus tunduk pada aturan-aturan kultural tertentu. Kita sudah memahami bahwa bahasa yang dipahami oleh KAMMI, karena proses identifikasinya, adalah bahasa mahasiswa. Tetapi, jangan lupa pula, KAMMI juga punya bahasa lain yang kemudian membedakannya dengan entitas-entitas mahasiswa yang lain (The Other Students): 'dakwah'. Bahasa ini merupakan jelmaan dari The Name of Father yang sudah ia pahami sejak ia berpisah dengan ibunya.

Ayah yang simbolik, begitu kata Lacan, memberikan basis aturanaturan yang mengharuskan si anak untuk tunduk ketika ia berbahasa. Ketika KAMMI mendeklarasikan dirinya di Malang pada 29 Maret 1998, ia mengenal 'bahasa'. Tentu saja, 'bahasa' itu dirujukkan pada name of father yang dimunculkan 'sang Ayah' Jemaah Tarbiyah. Bahasa dan artikulasi gerak KAMMI, dengan demikian menjadi terikat pada kendali 'Sang Ayah', yang tentu saja diejawantahkan dalam the-name-of-father: , doktrin, perintah, taklimat, atau qarar yang mengharuskan si anak untuk patuh. Itulah yang kemudian dikenal dengan nama 'dakwah'. Posisi subjektif ini mencirikan KAMMI sejak ia masuk pada fase bahasa: mahasiswa-dakwah.

Namun, celakanya, pada tahun 1998, 'Sang Ayah' mengubah posisi subjektifnya: ia menjadi partai politik! Di titik ini, jelas posisi subjektif KAMMI mengalami dilemma. Ia sudah mengukuhkan identitasnya dalam sebuah penanda-utama, yaitu mahasiswa-dakwah, dan dengan demikian menetapkan posisi subjektifnya. Diskursus Sang "Pendakwah" mengharuskannya untuk bergerak secara terorganisir dan mengikuti tanzhim dakwah. Namun, ketika posisi subjektif 'sang Ayah' itu berubah dan bertentangan dengan posisi subjektifnya, jelas posisi subjektifnya harus berubah dalam artian, ia harus mencari cermin baru untuk mengubah identifikasinya.

Pada titik inilah KAMMI mengalami kegalauan. Kita bisa membaca kegalauan ini berlangsung bahkan hingga sekarang! Di satu sisi, KAMMI ingin mempertahankan identitasnya sebagai mahasiswa. Namun, di lain sisi, KAMMI tak bisa berlepas diri dari superioritas 'Sang Ayah'. Ada semacam 
taboo yang menghalangi KAMMI untuk benar-benar mandiri/independen dari sang Ayah, ini terkait dengan konstruksi budaya yang ditanamkan 'Sang Ayah' kepada KAMMI.

Pada diskursus tentang organisasi (tanzhim) yang ada di Jamaah Tarbiyah, ada dua konsep penting yang mengikat setiap artikulasi anggota tanzhim dalam satu kesatuan: al qiyadah wa al jundiyah dan al hizb huwa al jama'ah wa al jama'ah hiya al hizb. Konsepsi pertama merujuk pada pengorganisasian model militer, di mana relasi pengurus dan anggota adalah relasi pemimpin dan tentara, sementara konsepsi kedua merujuk pada penyatuan tanzhim dengan partai, konsep yang di Ikhwanul Muslimin dirumuskan di tengah dekade 80an.

Dua konsepsi tersebut melahirkan taboo meminjam Freud. Jika KAMMI keluar dari pakem itu, ia akan dieksklusi dari jamaah. Tentu saja, ini tak diinginkan oleh KAMMI. Jika ia keluar dari jamaah, rasanya tak hanya membingungkan, tetapi juga menyakitkan! Namun, hal serupa juga terjadi pada posisi subjek KAMMI sebagai mahasiswa. Inilah yang menyebabkan terjadi semacam kegalauan di tubuh KAMMI, yang lama-kelamaan, menyebabkan KAMMI kebingungan menentukan bahkan jenis kelaminnya sendiri, antara independen dari partai politik atau menyatu dengan partai politik.

Kebingungan ini kemudian akan dapat kita lihat pada artikulasi gerak KAMMI di tahun 2000-an. Dari tahun 1998-2000, KAMMI 'sukses' mengawal proses-proses demokratisasi dengan memosiskan dirinya sebagai pressure group: menekan kebijakan-kebijakan transisi yang dianggap liberal. Pada titik ini, posisi subjektif KAMMI inheren dengan posisi politik partai yang juga kritis. Namun, lain halnya dengan KAMMI setelah tahun 2000. Kita akan menemukan sebuah kasus penting: Muktamar Luar Biasa KAMMI di Bandung, awal tahun 2001, yang menurunkan Andi Rahmat dari kedudukannya sebagai Ketua Umum KAMMI.

Saya mendapatkan beberapa keterangan dari pelaku sejarah. Dalam pidatonya, juga diperkuat oleh rilis resmi KAMMI pasca MLB, Andi Rahmat menyatakan mundur karena ia merasa gagal mengelola organisasi sebesar KAMMI (pidato, 2003). Tetapi, tentu saja, intervensi tangan tak terlihat atau 'Jamaah Tarbiyah yang sudah bertransformasi menjadi partai politik sangat terasa. Seorang alumnus menyatakan, peserta didatangkan jauh-jauh dari daerah atas instruksi elit-elit PKS. Penyebabnya sederhana: Andi Rahmat punya jalan pikiran sendiri untuk tidak berkontribusi menurunkan presiden Gus Dur, sementara di sisi lain Jamaah menyatakan Gus Dur harus turun. 
Pada titik inilah persinggungan posisi subjektif KAMMI dan PKS terjadi. Jelas, PKS tak bisa menerima KAMMI punya jalan pikiran sendiri, ia harus mendisiplinkan 'si anak'. Di sisi lain, KAMMI sendiri mencoba untuk melanggar taboo. Ia melanggar perintah sang ayah. Ini akhirnya menyebabkan KAMMI sendiri kena marah, dan akhirnya harus menerima kenyataan didisiplinkan. Kondisi seperti ini, beberapa kali terjadi. Atas dasar yang sejenis walaupun alasannya ada yang lebih personalterjadi proses pergantian kepemimpinan 'luar biasa' di tahun 2001 dan pertengahan tahun 2009.

Yang jadi persoalan bukanlah mengapa hal semacam ini bisa terjadi, tetapi pertanyaannya, mengapa posisi seperti ini bertahan bahkan hingga 15 tahun hampir tanpa resistensi? Bukankah KAMMI juga memiliki hasrat sendiri yang membuat posisinya sebagai subjek mampu memilih? Jawaban yang bisa kita tebak adalah bahwa hasrat KAMMI telah diinterpelasi. Ini berarti bahwa kegalauan KAMMI itu terjadi bukan karena KAMMI menginginkannya Ada kekuatan lain yang mengendalikan hasrat KAMMI sehingga seluruh artikulasi KAMMI akan mengarah pada identifikasi penanda tertentu. Superioritas PKS sebagai 'Sang Ayah' memungkinkannya untuk mempengaruhi subjek agar masuk dan bertindak dalam sebuah gejala kebudayaan tertentu.

Kita tentu akan bertanya, apa yang menyebabkan 'Sang Ayah' begitu marah hingga mendisiplinkan anaknya ketika anaknya 'bandel'? Argumen Lacanian akan menjawab, kemarahan sang Ayah terjadi karena anaknya dianggap keluar dari kebudayaan, dan kewajiban sang ayah-lah untuk membuat anaknya kembali pada kebudayaan itu! Dalam bahasa Foucault, hal ini disebut sebagai proses 'disiplin' yang bertujuan mengembalikan subjek pada narasi kekuasaan yang dibangun. Tetapi kita tentu akan bertanya lagi, bentuk kebudayaan seperti apa yang kemudian diinginkan oleh 'Sang Ayah', terutama dalam konteks politik? Kita akan segera bertemu jawabnya ketika kita melihat pada diskursus Sang-Penikmat yang ditampilkan oleh Anis Matts: Kebandelan Sang-Anak akan mengeluarkan si anak pada diskursus Sang-Pekerja yang dikonstruksi oleh Sang Ayah, dan tentu saja, KAMMI harus ambil bagian dalam bekerja memenangkan dakwah yang dikomandani oleh sang Ayah. Jika si anak ingin mengambil posisi subjektif yang berbeda, Sang Ayah akan mengancam: kau akan dipisahkan dari kebudayaan jika membangkang!

Dengan demikian, proses 'disiplin' atau 'superioritas sang Ayah' hanya bisa dipahami dengan membaca struktur wacana yang dibangun oleh PKS. Setelah Orde Baru, PKS segera bertransformasi menjadi partai politik, dan dengan demikian mengubah posisi subjektif yang telah ia bangun sejak 1998 . 
Mereka mulai tampil di pentas Pemilu pada tahun 1999 dan mulai menjadi salah satu kekuatan politik utama tahun 2004. Dinamika posisi PKS dan hegemoni yang ia bangun atas semua entitas 'dakwah' dimana KAMMI juga berada di dalamnya akan didiskusikan di bawah ini.

\section{"Menikmati Demokrasi”: Terbangunnya Hegemoni PKS atas KAMMI}

Subjek Lacanian adalah subjek yang sepenuhnya sadar untuk menyerahkan dirinya pada Sang Ayah. Oleh sebab itu, proses penundukan tidak dilakukan melalui suruhan atau koersi, melainkan melalui hasrat. Artinya, untuk menundukkan subjek tertentu, tidak cukup hanya menanamkan diskursus, tetapi juga mengarahkan dan membentuk subjek mereka yang dilakukan dengan proses 'interpelasi hasrat' atau memunculkan hasrat-hasrat ketaksadaran yang memungkinkan sang subjek mengintervensi proses diskursus entitas yang ingin ia kuasai (Bracher, 2005: 31). Proses interpelasi hasrat itulah yang akan kita bicarakan pada bagian ini.

Ada dua jenis hasrat: hasrat narsistik yang berbentuk aktif dan pasif, serta hasrat anaklitik yang juga berbentuk aktif dan pasif. 'Hasrat narsistik', sebagaimana telah dijelaskan di atas, adalah 'hasrat untuk menjadi' (wants of being). Hasrat untuk mendapat pengakuan atas diri dari The Other. Hasrat narsistik aktif artinya ia berupaya untuk mengimitasi The Other menjadi Orang Lain. Sebagai contoh, KAMMI yang ingin menjadi Hassan Al Banna atau Syabaab Ikhwan dan mengimitasinya. Sementara hasrat narsistik pasif artinya ia berupaya untuk mendapatkan cinta dari The Other, semisal KAMMI yang ingin mendapatkan cinta/pengakuan diri dari PKS.

Adapun hasrat anaklitik adalah hasrat untuk memiliki. Hasrat ini, menurut Lacan, bisa terpuaskan. Hasrat anaklitik aktif, berarti subjek berhasrat untuk memiliki orang-lain sebagai cara untuk mendapatkan kepuasan. Contohnya, KAMMI yang berhasrat untuk memiliki BEM di kampusnya atau kursi Bupati di daerahnya untuk memuaskan 'hasrat'nya. Sementara itu, hasrat anaklitik pasif berarti hasrat untuk dihasrati oleh orang-lain, yaitu ketika diri menjadi alat untuk memuaskan hasrat orang lain. Ini berhubungan dengan 'hasrat anaklitik aktif' orang lain, yang membuat KAMMI menjadi 'objek' dari orang-lain.

Interpelasi 'hasrat' terjadi ketika KAMMI 'diajak' untuk mengambil satu posisi/disposisi subjektif tertentu. Keempat jenis hasrat tersebut tentu saja tidak bisa dipuaskan pada saat yang bersamaan. Hasrat anaklitik aktif seseorang menjadikan orang lain sebagai objek. Artinya, ada semacam 'pertarungan' di sini, siapa yang lebih superior untuk menginterpelasi hasrat orang lain. Jika 
yang superior adalah subjek A, ia akan menjadikan B sebagai objek hasratnya. Juga sebaliknya, dan berlaku pula pada 'nasrat harsistik'.

Relasi KAMMI dan PKS bisa dilihat pada relasi ini. Untuk membangkitkan 'hasrat narsistik' dan 'hasrat anaklitik' KAMMI, hasrat KAMMI harus terlebih dulu diinterpelasi. Ada tiga cara interpelasi tersebut melalui penanda utama, citra, dan fantasi. Ketiga cara ini bisa dilihat operasinya dalam penciptaan diskursus tentang demokrasi: Diskursus Sang Penikmat dan Diskursus Sang Pekerja.

Pada tahun 2002, Anis Matta menulis buku yang berjudul "Menikmati Demokrasi” . Tulisan itu memang hanya kumpulan artikel-artikel lepas yang ditulisnya tentang politik, tetapi kita bisa mengambil sebuah posisi penting PKS di sini: PKS menjadikan aktivitas politiknya sebagai aktivitas pemenuhan hasrat dari apa yang ia sebut sebagai 'demokrasi'. Di buku tersebut, Anis Matta bicara banyak soal bagaimana kader-kader dakwah berpartisipasi dalam prosesproses demokratisasi di Indonesia (Matta, 2002: 1). Hal ini diafirmasi oleh karya lain, misalnya, Cahyadi Takariawan yang terang-terangan menyatakan bahwa Tarbiyah sudah memasuki era mihwar dauly dan mengharuskan kaderkader untuk mampu bergerak seiring dengan kompleksnya proses-proses politik yang ada (Takariawan, 2009: 8). Dengan demikian, logika berpolitik dapat kita identifikasi sebagai logika jouissance, penikmatan, pemenuhan hasrat. Konteks 'menikmati demokrasi' akan kita jadikan latar belakang untuk membicarakan artikulasi PKS setelah tahun 2004.

Pada tahun 2004, PKS secara resmi memulai apa yang secara politis disebut sebagai koalisi PKS bergabung dan mendapatkan posisi dalam pemerintahan. Posisi PKS sebagai bagian dari pemerintahan akan mengimplikasikannya untuk mengambil posisi subjektif berbeda. PKS tidak lagi menjadikan eksekutif pemerintahan sebagai 'lawan', melainkan ia sendiri berada pada posisi tersebut.

Bagi PKS, itu berarti ia harus mengubah posisi subjektifnya, pada titik inilah istilah 'menikmati demokrasi' kemudian dikumandangkan. Apa artinya menikmati? Slavoj Zizek menggambarkan hal ini secara lebih konkret. Kenikmatan pada dasarnya inheren dengan proses konsumsi di era new spirit of capitalism, "kita membeli sebuah produk bukan karena kita memerlukannya, melainkan karena kita ingin membuat hidup kita lebih senang dan berarti (Zizek, 2009: 53). Kapitalis menikmati demokrasi karena ia memberikan kesempatan pada orang-orang untuk membeli produk mereka. Begitu juga aktivis dakwah, ia menikmati demokrasi karena ia memberikan kebebasan 
untuk bertemu dan berinteraksi langsung dengan objek dakwah, yakni prosesproses demokratisasi.

Jika kita ubah perkataan Anis Matta ini, kita akan menemukan bahwa, "untuk mengisi demokrasi, kita harus menikmatinya". Ini setipe dengan katakata Zizek, kita membeli barang karena kita menikmatinya! (Zizek, 2009). Secara psikoanalitis, ini artinya, berpolitik berarti memenuhi hasrat kita untuk memiliki arena politik itu ("demokrasi"). Anis Matta menampilkan hasrat anaklitik aktif kepada proses demokrasi. Ia (dan juga PKS tentu saja) ingin demokrasi itu dimiliki, dihasrati, dan dijadikan alat pemuasan keinginan dakwah.

Tapi, kita belum sampai pada argumennya. Bagi Anis Matta, menikmati demokrasi itu ada harganya, karena baginya pelaku kemungkaran juga punya kesempatan yang sama, bisa jadi punya hasrat yang sama. Ini artinya, wacana demokrasi itu harus direbut! Anis Matta punya tiga argument di sini: Pertama, menangkanlah wacana publik agar opini publik berpihak kepada kita. Kedua, formulasikan wacana itu ke dalam draf hukum untuk di menangkan dalam wacana legislasi melalui lembaga legislative. Kemenangan legislasi ini menjadi legitimasi bagi Negara untuk mengeksekusinya. Ketiga, pastikan bahwa para eksekutif pemerintah melaksanakan dan menerapkan hukum tersebut (Islamedia, 2012: 110).

Jika kita lihat formula di atas, maka bisa kita lihat: bagi PKS, demokrasi adalah sesuatu yang dinikmati, namun tentu saja memerlukan sedikit 'usaha': 'menikmati demokrasi' membutuhkan kerja! Konsekuensinya, agar bisa menikmati demokrasi, maka semua elemen dakwah harus bekerja. Kata-kata "kerja" kemudian menjadi jargon PKS di masa-masa berikutnya ("bekerja untuk Indonesia”, "Cinta, Kerja, dan Harmoni”). Ingat, di sini Anis Matta menggunakan kosakata "dakwah", yang tentu saja tidak hanya merujuk pada penanda PKS tetapi juga seluruh elemen yang berkategori sebagai aktivis dakwah.

Dengan demikian, Diskursus "Sang-Penikmat" berimplikasi pada diskursus "Sang-Pekerja” semua elemen 'dakwah' harus bekerja memenangkan dakwah agar demokrasi bisa dinikmati. Bagi PKS, diskursus yang beroperasi adalah diskursus "Sang-Penikmat". Namun, bagi KAMMI elemen dakwahyang beroperasi adalah diskursus "Sang-Pekerja". Maka, tak heran jika kita akan mendengar beberapa ungkapan berikut dari aktivis KAMMI, "bekerja lebih penting dari berpikir", atau "yang penting karya nyata, bukan wacana”, dan sejenisnya. 
Konsekuensi inilah yang kemudian memberikan pengaruh terhadap KAMMI. Mari kita kembali pada diskusi sebelumnya. Perubahan posisi subjektif yang dilakukan oleh PKS berimbas pada KAMMI, karena adanya upaya untuk merebut 'makna' demokrasi tersebut membutuhkan tenaga elektoral serta mobilisasi yang besar. Pada titik inilah doktrin jamaah muncul KAMMI tidak berada dalam posisinya sendiri, tetapi dibutuhkan sebagai bagian dari jamaah dakwah. Di sini, kita bisa mengambil sebuah posisi kritis: Sebetulnya, 'Sang Ayah' membutuhkan KAMMI sebagai alat. KAMMI menjadi semacam 'tombak' untuk menusuk partai lain dengan kekuatan mobilisasi yang ia miliki, dan menjadi kekuatan mobilisasi untuk kepentingan politiknya tanpa harus mengikutsertakan mereka secara formal.

Pada titik ini, muncul relasi-kuasa: PKS membutuhkan KAMMI dan menjangkarkan subjektivitas semua entitas dakwah melalui diskursus 'menikmati demokrasi'. Muncul pertanyaannya, apakah dengan demikian KAMMI juga ikut menjangkarkan KAMMI dengan sadar mengikutsertakan dirinya pada sistem penandaan yang dijangkarkan oleh PKS (diskursus Sang Penikmat), dan dengan demikian melegitimasi hegemoni yang sedang dibangun oleh PKS atas dirinya.

\section{Modus-Modus Interpelasi KAMMI oleh PKS: Kasus Century dan LHI}

Kemampuan untuk mempengaruhi subjek dalam satu gejala kebudayaan tertentu, sangat ditentukan oleh kemampuan untuk menginterpelasi hasrat. The Name of Father tidak dilakukan melalui suruhan atau koersi, melainkan melalui hasrat. Agar si anak mengikuti perintah 'Sang Ayah', hasratnya harus diinterpelasi dibangkitkan kerinduan mendasarnya sehingga ia mengikuti pola sang Ayah. Artinya, hegemoni itu tidak muncul begitu saja, melainkan dikonstruksi melalui praktik-praktik diskursif. Ada tiga modus interpelasi yang diteorisasikan oleh pendekatan Lacanian: Interpelasi melalui penanda-utama (master signifier), interpelasi melalui citra, dan interpelasi melalui fantasi (Bracher, 2005: 32-33). Dengan menginterpelasi subjek (KAMMI) melalui tiga cara tersebut, diskursus yang ditampilkan oleh PKS berjalan. Kita akan melihat praktik diskursif tersebut dalam penjelasan di bawah ini.

PKS menginterpelasi hasrat narsistik dan anaklitik PKS melalui penanda utama. Artinya, PKS mengosongkan penanda-utama yang dipahami oleh KAMMI dan mengisinya dengan penanda-utama yang mereka pahami. Sebagaimana dijelaskan pada bagian sebelumnya, penanda-utama yang dipahami oleh PKS berpusat pada dua hal: "mahasiswa" dan "dakwah". PKS 
menginterpelasi penanda utama tersebut dengan menguasai makna "dakwah". Hal ini mudah saja, sebab sejak ia berdiri, ia sudah mendeklarasikan dirinya sebagai partai-dakwah, membuat setiap makna yang-lain tentang dakwah akan merujuk pada dirinya sendiri.

Kemampuan PKS untuk membentuk sebuah diskursus-universitas (diskursus yang menundukkan system penandaan) terletak pada kemampuannya menjadikan penanda-utamanya beroperasi dan menundukkan penandautama yang lain (Bracher, 2005: 81). Ketika KAMMI mengidentifikasikan dirinya pada satu penanda-utama dakwah, artikulasi yang ia rujukkan akan bersandar ke aktivitas dakwah. PKS dengan superioritasnya menginterpelasi penanda-utamanya tentang dakwah itu, membuat artikulasi dakwah yang dipahami KAMMI melalui politik jalanan dan gerakan mahasiswa goyah, dan mau-tidak-mau KAMMI harus beranjak ke sana.

Untuk itu, ia perlu satu alat bantu: manhaj dakwah. Untuk menginterpelasi penanda-utama "mahasiswa", seluruh artikulasi tentang "dakwah" diintegrasikan dalam satu manhaj. Tentu saja, ini berarti memasukkan seluruh komponen yang mengartikulasikan dakwah sebagai penanda-utamanya pada sebuah kesatuan manhaj yang powerful. Yang paling utama dari manhaj ini adalah manhaj kaderisasi. Jadi, jika seseorang ingin menjadi bagian dari organisasi dakwah, ia harus ikut alur kaderisasi. Dengan menguasai kaderisasi, praktis, setiap orang yang ingin menjadi bagian dari aktivitas dakwah harus masuk ke proses ini. Tanpa harus memasukkan KAMMI sebagai organ underbouw-nya, ia telah menginterpelasi Hasrat KAMMI dalam menjadi bagian dakwah.

Ada cara lain untuk menginterpelasi 'hasrat' melalui citra. Cara ini berarti membangkitkan hasrat dengan cara menampilkan sesuatu yang menggetarkan emosinya. Emosi tumbuh dari citra yang didapatkan dari fase imajiner. Di fase cermin, identifikasi diri dihasilkan melalui citra, yang kemudian ditetapkan menjadi bahasa melalui proses simbolik. Namun, citra itu ternyata tidak hilang. Ia muncul sebagai emosi ketika seseorang melihat pada The Other nya dan kemudian, secara tidak sadar, ia menjadikan imajinasi tersebut sebagai referensi atas perilaku, sikap, dan tindakan yang akan seorang subjek lakukan (Bracher, 2005: 44-45).

Begitu juga dengan KAMMI. Interpelasi melalui citra dilakukan, misalnya, pada penyikapan-penyikapan gerakan. Kita bisa lihat hal ini secara jelas dalam kasus penangkapan Luthfi Hasan Ishaaq, Presiden PKS, yang kemudian disikapi oleh KAMMI (ini agak membingungkan, karena KAMMI selalu mengatakan bahwa ia bukan underbouw PKS). Ada satu petikan berita 
menarik dari Ketua Umum PP KAMMI (2011-2013), Muhammad Ilyas, yang mungkin bisa menggambarkan interpelasi melalui citra tersebut,

Menurut Ilyas, ada kasus yang terang benderang di depan mata, namun tidak dituntaskan oleh KPK. Kasus itu adalah kasus Century dengan nilai 6.7 Trilyun dan kasus BLBI dengan nilai sekitar 500 Trilyun. Kedua kasus itu melibatkan Wakil Presiden Boediono."Kenapa KPK tidak mengungkap kasus Boediono. Apakah KPK takut sama Boediono?" kata Ilyas kepada Kabar Kampus, (01/02/2013).

Ilyas menjelaskan, bahwa ia mengenal mantan presiden PKS tersebut sebagai orang yang berintegritas. Namun terlibat atau tidaknya Luthfi itu sangat manusiawi. Dalam kesempatan itu Ilyas menegaskan bahwa organisasinya bukan underbouw PKS. Anggota KAMMI yang bergabung dengan PKS adalah personal.

Apa yang bisa diambil dari petikan di atas? Petikan pertama menampilkan citra tentang ketakutan KPK terhadap Boediono yang dijadikan dasar oleh Ketua Umum KAMMI untuk mempertanyakan KPK. Ketua KAMMI menempatkan kasus Century sebagai cermin, sebagai alat untuk membandingkan kasus itu dengan kasus LHI. Tetapi, tentu saja yang ditangkap KAMMI kemudian adalah citraan yang dipertegas dengan emosi. Citraan itu dapat dilihat, misalnya, dari pertanyaan, "Apakah KPK takut sama Boediono?" Meskipun ini hanya dugaan, tetapi jelas apa yang ditangkap oleh Ilyas adalah citra. Bagaimana Ilyas bisa menyimpulkan bahwa KPK 'takut'? Pertanyaannya, adalah bagaimana ini bisa terkonstruksi pada diri KAMMI.

Sementara itu, petikan kedua dari berita yang sama melihat citra itu pada diri Luthfi Hasan Ishaaq. "Ia mengenal Presiden PKS tersebut sebagai seorang yang berintegritas". Tetapi, lagi-lagi, itu adalah citra. Bagaimana Ilyas bisa menyimpulkan bahwa Presiden PKS itu berintegritas? Identifikasi semacam itu jelas adalah citra sesuatu yang ditangkap oleh subjek dari hasil pencerminan. Kedua citra di atas lahir ketika Ilyas mencerminkan Luthfi Hasan Ishaaq dan KPK dengan The Other. Dengan mencerminkan LHI dengan keseharian pergaulannya sehari-hari, ia menangkap citra bahwa LHI adalah orang yang berintegritas. Dan juga, dengan mencerminkan KPK dengan kasus Boediono, ia menangkap citra bahwa KPK takut dengan Boediono.

Lantas, bagaimana citra itu bisa melekat pada diri seorang Ketua Umum KAMMI? Jawabnya langsung bisa kita temukan di statement berikutnya: "KAMMI dan PKS hanya memiliki hubungan emosional. Secara institusi kami Independen”. Hubungan emosional itulah yang membentuk citra. 
Secara teoretis, citra hanya bisa ditangkap jika ada konstruksi emosional yang ditangkap oleh si-penerima dari si-pemberi. Ketika melihat kasus LHI, misalnya, hubungan emosional yang terbentuk antara PKS dengan KAMMI dalam hal ini Ilyas memberikan ia konstruksi yang nyaris persis: bahwa LHI tidak bersalah. Dan hubungan emosional itu pula yang melahirkan citra bahwa KPK takut terhadap Boediono kita bisa lihat beberapa statement dari politikus macam Mahfudz Sidiq atau Fahri Hamzah untuk membuktikan ini.

Pendeknya, PKS menggunakan citraan yang dikonstruksi secara emosional untuk menginterpelasi KAMMI. Cara ketiga untuk menginterpelasi adalah melalui fantasi. 'Fantasi' adalah apa yang menggiring seseorang untuk melakukan sesuatu tanpa harus mengetahui apa yang ada pada pengetahuan itu. Ada argumen Marx yang cukup terkenal yang kemudian digubah oleh Slavoj Zizek, yaitu 'they do not know it, but they are doing it'. Seorang subjek tidak 'sadar/tahu' tentang sesuatu (dalam kesadarannya) tetapi pada praktiknya ia tetap melakukan itu karena dorongan ketaksadarannya. Inilah yang disebut sebagai ideological fantasy (Zizek, 1989: 30). Fantasi-fantasi ideologis ini bekerja, misalnya, dalam fethisisme (semisal uang). Sesuatu yang fethish dipuja karena ia memiliki nilai mitis yang bisa membuat orang-orang masuk pada jerat sistem penandaan yang ia miliki. 'Nilai mitis' inilah yang kemudian kita identifikasi sebagai fantasi. Bagi subjek yang diinterpelasi, fantasi memberikan rasa suka-cita dan penikmatan tanpa ada sesuatu yang bisa dinikmati, penikmatan itu berada dalam imaji (Zizek, 1989: 47).

PKS menginterpelasi hasrat KAMMI melalui penciptaan fantasi-fantasi semacam itu. Kita bisa lihat, misalnya, pada "fantasi" mengenai kekayaan. Anis Matta spesial menulis tiga seri tulisan tentang 'uang' untuk menciptakan fantasi mengenai kader yang kaya. Anis Matta tahu, aktivis-aktivis KAMMI bukanlah kader-kader yang kaya secara finansial. Untuk menginterpelasi hasrat KAMMI, maka diciptakanlah fantasi tentang kader yang bisa berdakwah dengan lebih baik melalui penguasaan atas 'uang'. Dengan menulis tentang 'uang', fantasi tentang dakwah yang mapan, gerakan yang mampu menguasai sumber daya ekonomi, atau KAMMI yang bisa membiayai aktivitasnya secara mandiri, langsung terbayang dan memberikan kenikmatan tersendiri tetapi itu hanyalah fantasi.

Dengan fantasi ini, aktivitas pergerakan KAMMI setelah tahun 2004 dapat kita lihat implikasinya: menjadi sangat berorientasi pada pencarian sumber daya finansial. Ini bukan berarti tidak dilakukan sebelum 2004, namun menjadi sangat menonjol ketika PKS duduk di kursi pemerintahan, 
anggaran-anggaran publik lebih terbuka untuk diakses, dan KAMMI tidak lagi menampakkan kegarangannya setidaknya lebih slow dibanding sebelumnya di depan pemerintah. Sejak 2006, kita menyaksikan aktivitas yang lebih berbasis pada pengokohan finansial dan interaksi yang lebih 'manis' dengan institusi-institusi pemerintahan.

Apalagi, dengan adanya istilah mihwar dauli di mana dakwah masuk pada ranah 'negara' dan konsekuensinya harus menguasai sumber daya yang memungkinkan Jemaah mengakuisisi sedikit-demi-sedikit posisi negara fantasi mengenai gerakan yang mapan ini semakin menghujam ke diri KAMMI. Persoalannya, apa yang kemudian bisa dilakukan agar gerakan KAMMI punya banyak uang? Tentu saja, menggunakan relasi dan jejaring dengan partai menjadi salah satu shortcut. Aktivasi kedekatan dengan sumber dana memungkinkan KAMMI menerima dana-dana publik. Lahirlah, dari sini, aktivis pemburu-rente, broker, dan lain sebagainya. Ini mungkin sah saja dan legal, tetapi, secara psikoanalitis, mencerminkan satu hal: interpelasi 'hasrat' KAMMI melalui penciptaan fantasi tentang 'KAMMI yang-kaya'.

Penjelasan mengenai modus interpelasi di atas menunjukkan beroperasinya hegemoni 'PKS' atas 'KAMMI' yang ironisnya, dilakukan dengan menginterpelasi hasrat KAMMI dan beroperasi dalam posisi subjektif KAMMI sendiri. Hal ini yang membuat pembicaraan tentang 'independensi' KAMMI seperti menemui jalan buntu. 'Independensi' KAMMI memang termaktub dalam konstitusi, namun artikulasi yang ditampilkan jauh sekali dari itu. Psikoanalisis membantu kita untuk memahami bahwa hal tersebut terjadi tidak hanya karena proses-proses hegemonisasi sebagaimana ditunjukkan dalam pembacaan Foucauldian yang saya tampilkan dalam artikel sebelumnya tetapi juga karena adanya interpelasi hasrat yang memungkinkan adanya peran-peran subjektif KAMMI sendiri.

\section{Simpulan}

Lantas, bagaimana kita memahami relasi KAMMI dan PKS selama ini? Tulisan ini memulai dari proses 'identifikasi' diri KAMMI di awal pendiriannya sebagai bagian besar dari Jamaah Tarbiyah yang mengaksentuasikan dakwah. Menggunakan kompleks Oedipus yang diajukan Lacan, tulisan ini berargumen bahwa citra 'KAMMI adalah PKS' sejatinya adalah citra yang diberikan oleh PKS melalui interpelasi hasrat. Kepentingannya adalah untuk mengenalkan si anak pada kebudayaan dan menjadikan si anak sebagai alat untuk meraih hasratnya. Ia menjadikan KAMMI sebagai objek yang dimiliki, dihasrati, 
yang menyiratkan hasrat anaklitik tersendiri. Hal tersebut dilakukan melalui interpelasi hasrat. Dengan menginterpelasi proses-proses subjektivitas KAMMI, PKS kemudian menjadi The Big Other yang dijadikan 'cermin' KAMMI atas segala aktivitasnya, membuat KAMMI menjadi dependen, secara tidak sadar, atas PKS dan mengokohkan hegemoni PKS atas KAMMI.

Artikel ini berkesimpulan bahwa untuk melihat relasi antara gerakan mahasiswa dan partai politik, perlu dilihat proses subjektivisasi yang tumbuh pada gerakan mahasiswa apapun bentuknya. Hampir semua gerakan mahasiswa di Indonesia, baik dalam bentuk BEM maupun gerakan ekstrakampus (KAMMI, IMM, PMII, HMI, dll) tidak lepas dari cengkeraman partai politik. Psikoanalisis Lacanian berkontribusi dalam menjelaskan bagaimana hal tersebut terjadi dengan melihat proses pertumbuhan gerakan-gerakan mahasiswa pasca-reformasi. Jika melihat kasus KAMMI dan PKS, eksodus alumni dan akar ideologi yang memproliferasi gerakan membuat keterikatan antara dua elemen tersebut semakin kuat. Hal ini, kendati terjadi dengan cara yang berbeda juga terjadi pada gerakan-gerakan mahasiswa yag lain seperti PMII, IMM, atau HMI yang punya banyak alumnus dan kepentingan politik di gerakan mahasiswa.

Hal menarik yang perlu dicatat adalah proses proliferasi tersebut dimungkinkan dengan adanya proses demokratisasi di Indonesia setelah tahun 1998. Analisis yang lebih komprehensif tentang gerakan mahasiswa secara umum (tidak hanya KAMMI dan PKS) akan membantu kita memahami masalah ini secara lebih mendalam.

\section{Daftar Pustaka}

Aspinall, Edward. 2012."Indonesia: Moral Fonce Politics and the Struggle against Authoritarianism" in Meredith L. Weiss and Edward Aspinall (eds). Student Activism in Asia: Between Protest and Powerlessness. Minnesota, Utah: Minnesota University Press.

Aspinall, Edward. 2012. "Still an Age of Activism?" Inside Indonesia 107, January-March. Retrieved from http: //www.insideindonesia.org/weekly-articles/still-an-ageof-activism

Bracher, Mark. 2005. Jacques Lacan, Diskursus, dan Perubahan Sosial. Terjemahan. Yogyakarta: Jalasutra.

Foucault, Michael. 1991. "Governmentality" dalam Akhil Gupta (ed). Anthropology of The State. New York: Blackwell. 
Imam, Rijalul. 2010 "Tafsir Epistemik Prinsip Perjuangan KAMMI : Agenda dan Mihwar Gerakan Keummatan” dalam Rijalul Imam, dkk. Kapita Selekta. Jakarta: Muda Cendekia.

Kurniawan, Akbar Tri. 2013. "Kedaulatan KAMMI”. Dimuat ulang di Jurnal KAMMI Kultural, 15 Februari.

Lacan, Jacques. 1995. "The Mirror-phase as Formative of the Function of The I" in Slawoj Zizek (ed). Mapping Ideology. London: Verso.

Lacan, Jacques. 1977. Ecrits: A Selection. New York: Tavistock.

Laclau, Ernesto dan Chantal Mouffe. 1985. Hegemony and Socialist Strategy. London: Verso.

Machmudi, Yon. 2006. "Islamising Indonesia: The Rise of Jemaah Tarbiyah and Prosperous Justice Party (PKS)”. PhD Dissertation, unpublished. Canberra: Australian National University.

Matta, Anis. 2002. Menikmati Demokrasi. Solo: Era Intermedia.

Matta, Anis. 2009. "Serial tentang Uang". Seri Ceramah, tidak dipublikasikan.

Muhtadi, Burhanuddin. 2012. Dilema PKS: Suara dan Syariah. Jakarta: Gramedia.

Polimpung, Hizkia Yosie. 2008. "Ilusi Dekolonisasi: Psikoanalisis Lacanian dan Rekonstruksi Kolonialisme Barat”, Global E Strategis, Vol. 2 No. 1 : 98-125.

Rahmat, Andi dan Muhammad Najib. 2007. Gerakan Perlawanan dari Masjid Kampus. Yogyakarta: Profetika, cetakan kedua.

Sidiq, Mahfudz. 2003. KAMMI dan Pergulatan Reformasi. Solo: Era Intemedia.

Sudarsono, Amin. 2010. Ijtihad Membangun Basis Gerakan. Jakarta: Muda Cendekia.

Takariawan, Cahyadi. 2009. Menyongsong Mihwar Daulah: Mempersiapkan Kader-Kader Dakwah Menjadi Pemimpin Negara. Solo: Era Intermedia.

Thom, Martin. 2003. "The Unconscious Structured as Language" in Slawoj Zizek. (2003). Jacques Lacan: Critical Evaluations in Cultural Theory. London: Routledge. 
Zizek, Slavoj. 1989. The Sublime Object of Ideology. London: Verso.

Zizek, Slavoj, eds. 1995. Mapping Ideology. London: Verso.

Zizek, Slavoj. 2009. First as Tragedy, then as Farce. London: Verso.

Berita dan Dokumen

"KAMMI Tuntut Gus Dur Mundur" Gatra, 24 April 2001.

"Kata Presiden KAMMI soal Dugaan Suap Mantan Presiden PKS”. Kabar Kampus, 1 Februari 2013.

Anggaran Dasar dan Anggaran Rumah Tangga KAMMI. Jakarta: PP KAMMI.

Garis Besar Haluan Organisasi KAMMI. Jakarta: PP KAMMI.

Milis KAMMI.

Andi Rahmat. "Pengunduran Diri sebagai Ketua Umum PP KAMMI" Pidato, Muktamar Luar Biasa KAMMI 2001. 